\title{
THE EARLIEST EVIDENCE FOR DWELLING CONSTRUCTION IN THE UPPER PALAEOLITHIC OF EASTERN EUROPE: A 30,000-YEAR-OLD SURFACE STRUCTURE FROM MIRA LAYER I
}

\begin{abstract}
The purpose of this article is to present data on the surface structure identified in the upper layer of the Mira site in the Dnieper valley. The occupation of layer I, based on a set of consistent data, constitutes the remains of a seasonal winter camp of Pleistocene horse hunters. Ten available radiocarbon dates place the calibrated age of layer I between 31,000 to $28,000 \mathrm{cal}$ BP. The rapid albeit gentle overlapping of the settlement remains with alluvial sediments ensured that the original settlement and dwelling patterns and their elements survived well. Thanks to this, it is possible to reconstruct some significant aspects of the construction process, as well as details of the arrangement of the dwelling's interior space. A 30,000-year-old, permanent skeleton cylindrical yaranga type surface construction from Mira layer I is currently representing the oldest dwelling known in the Upper Palaeolithic of Ukraine and a broader context of the steppe zone of the East European plain.
\end{abstract}

Keywords: Upper Palaeolithic, surface dwelling, Eastern Europe.

\section{INTRODUCTION}

The earliest evidence for the construction of artificial shelters/dwellings in Eastern Europe are dated back to the late Middle Palaeolithic (Anisyutkin 2013; Chernysh 1982; 1987; 1989; Demay et al. 2012; Stepanchuk 2020) and revealed in the western segment of the geographical area. Upper Paleolithic dwellings are widely known in the steppe zone of Eastern Europe (e.g. Abramova 1997; Sapozhnikov, Sapozhnikova 2002; Gavrilov 2016). A well-known and bright feature of east European UP is dwellings constructed from mammoth bones. These are revealed at Mezin, Mezhirichi, Gontsy and other Epigravettian sites of the Middle Dnieper region (e.g. Pidoplichko 1969; 1976; Gladkikh, Kornietz 1979; lakovleva, Djindjian 2014; 2018; Shydlovskyi et al. 2019). Thus, the age of most East European dwellings does not extend beyond the late Upper Palaeolithic period, between 19,000-12,000 BP (Chernyshov 2006).

Remains of the significantly older UP dwelling were identified at the Mira site. Mira is located in the middle part of the Dnieper River valley (Fig. 1). Stratigraphic record encompasses almost $13 \mathrm{~m}$ of sedimentary succession (Gerasimenko, Haesaerts 2013; Matviishina 2013; Haesaerts et al. 2014; Hoffecker et al. 2014) and includes three layers sandwiched between two sandy bodies of Dnieper alluvia.
Layer I represents a seasonal autumn-winter occupation located near the place of successful hunting of a harem herd of a Pleistocene horse (Stepanchuk 2013; Stepanchuk et al. 2004; Hoffecker et al. 2014). Many various pits, postholes, hearths, bone and ashes accumulations etc. were revealed in layer I (Fig. 2) which stratigraphic features and spatial pattern allow recognizing remains of surface dwelling construction. The radiocarbon age of layer $\mathrm{I}$ is defined between 31,000 to 28,000 cal BP and therefore the Mira layer I construction is chronologically the oldest Upper Palaeolithic dwelling so far revealed in the steppe zone of Eastern Europe.

\section{MIRA LAYER I, GENERAL INFORMATION}

GEOGRAPHICAL POSITION. Mira represents an open-air Palaeolithic site recovered in the mid-1990s in the body of a 30-m terrace of the right bank of the Dnieper River valley in central Ukraine.

Two Upper Palaeolithic occupations (layer I and layer II/2) and an intermediate layer of natural fire (layer II/1) were identified in the lower part of 13-meter thick profile uncovering deposits of the upper part of the terrace (Gerasimenko, Haesaerts 2013; Matviishina 2013; Haesaerts et al. 2014; Hoffecker et al. 2014). Gray-greenish sandy loams containing remains of three archaeological layers appeared to be sandwiched between two sandy bodies of Dnieper 
alluvia and covered by subaerial sediments comprising late Pleistocene and Holocene sediments.

INDUSTRIES AND ANALOGIES. The closest East European Upper Palaeolithic analogies for the layer I lithic industry are seen in the Gorodtsovian assemblages of the River Don area (Anikovich et al. 2007; 2008; Sinitsyn 2015). The assemblage of the lowermost layer II/2 is fully Upper Palaeolithic in its technological and morphological characteristics and also has no regional analogies but finds a close analogy in a geographically remote assemblage of Paglicci 24A1 (Stepanchuk, Vietrov 2021). An intermediate layer II/1 contains only a few bones and flint artefacts that may have migrated from the uppermost layer I via bioturbation.

LAYER I LITHIC ASSEMBLAGE. The flint assemblage of layer I includes somewhat more than 54,000 lithics, of which almost $97 \%$ are tiny micro-flakes that appeared due to repeatedly operations of repair and sharpening, as well as knapping of a limited number of flint pieces. Remote lithic raw materials were used mainly (Petrougne 2001-2003; Stepanchuk, Petrougne 2008). Points, sidescrapers, endscrapers, forms combining elements of end scraper - side scraper - point, burins, pointed blades, pieces esquielles, retouched flakes, blades and bladelets are defined. Industry includes a few atypical Krems/ Font-Yves points, micro points and microtruncations on bladelets, two varieties of Dufour bladelets, and morphologically peculiar non-geometric microliths of Mira type (Stepanchuk 2013). Lithic assemblage of layer I does not have full regional analogies, and although the nearest parallels are found in the materials of the local East European Gorodtsovian industry (Sinitsyn 2015), it also contains bifacial pieces, among which are complete and fragmented foliates, points, and convergent side scraper (Stepanchuk 2013; 2019).

CHRONOLOGY. The layers I, II/1, and II/2 are regarded as chronologically close. Time intervals that separate them are believed to be range from just a few decades to several hundred years (Gerasimenko, Haesaerts 2013). The total thickness of the sediments containing the remains of layers I, II/1, II/2, and archaeologically sterile horizons between them, does not exceed $40 \mathrm{~cm}$. The maximum thickness of Mira Layer I is up to $10 \mathrm{~cm}$ with a norm of 7 to $9 \mathrm{~cm}$ in rich areas. 19 radiocarbon dates are reported for the Upper Palaeolithic sequence of the site (Stepanchuk 2013; 2019; Hoffecker et al. 2014; Haesaerts et al. 2014). Ten dates place the calibrated age of layer I between 31,000 to 28,000 cal BP (Stepanchuk, Vietrov 2021).

FAUNAL REMAINS. Layer I is rich in faunal remains sometimes forming bone breccia. Faunal assemblage at Mira layer I is crucially dominated by Equus latipes, followed by Vulpes vulpes. Remains of large mammals also involve a limited number of bones identified as belonging to Bison priscus, Cervus elaphus, Megaloceros giganteus, and Rangifer tarandus (Stepanchuk et al. 2004; Hoffecker et al. 2014; Zhuravlev 2015; Zhuravlev, Puchkov 2001-2003). A moderate climate is reconstructed based on the available environmental evidence (Gerasimenko, Haesaerts 2013; Haesaerts et al. 2014).

PALEOENVIRONMENTAL FEATURES OF THE SITE. After P. Haesaerts and N. Gerasimenko (2013; Gerasimenko 2001-2003) about 32,000 cal BP, a cape or an island has been formed at the place of the future site. The surface of this subaerial area was subjected to the intensive and stable process of soil formation, though was sometimes flooded during spring high waters. A floodplain terrace formed here was characterized by herbaceous meadow vegetation, and pine and probably broad-leaved trees. An open landscape with small elevations covered by woody shrub vegetation was dominant near the site. The periodically flooded lowered areas were occupied by dense herbaceous vegetation, marshes existed in the riverside area. More remote areas were dominated by forest-steppe landscapes (Sirenko et al. 1990; Kunitsa 2007; Melnychuk 2004; Matviishina et al. 2010; Rudenko 2007).

Two buried soils are recognized in the sediments of this terrace. Remains of the occupation of layer II/2 were traced in the lower buried soil. Occupation of layer I correlates with the uppermost part of the upper buried soil, while layer II/1 correlates with the lower humus of the same buried soil. During the period 28,000 to 26,000 cal $\mathrm{BP}$, after the abandonment of the site, the area has experienced a rhythmic and steady rise in water level. The level with remains of Paleolithic occupations was gradually submerged and gently covered with alluvial sediments. Later the area of the site has been covered by channel alluvium and entered the sub-aquatic phase. New crucial landscape change occurred about 28,000 and since that time the area remains in subaerial conditions. In general, over the last 35 thousand years, the landscape of the area has experienced up to 25 landscape shifts associated with global climate change (Gerasimenko, Haesaerts 2013).

\section{OCCUPATION OF MIRA LAYER I: TAPHONO- MY, SPATIAL PATTERNS AND STRUCTURAL ELE- MENTS, EVIDENCE FOR HUMAN ACTIVITIES AND INTERPRETATIONS}

Sediments included remains of human activity do not exhibit evidence of intense water erosion and redeposition, cryogenic transformations, and active bioturbation. All three archaeological layers are horizontal and show only minor depressions and elevations. Layer I is slightly inclined toward NEE and NE. The majority of finds in layer I lies either horizontally or sub-horizontally. 
Practically all flint artefacts show no signs of patina and water erosion. The strikingly high proportion of micro-flakes and debris, which is more than $97 \%$, indicates the high level of preservation of the layer. The preservation of the pits and their boundaries is quite high. But the fauna has not survived very well, as a result of the post-accumulation history of the layer.

Different areas of layer I differ in the number of flint, stones, bones and other finds. The concentration of finds is increasing towards the southeastern segment of the excavated area (Fig. 3), while the northwestern segment provides significantly less numerous and mostly faunal residues.

The central and peripheral zones of the occupation are well recognized based on the concentration of residues. Evidence of the most intensive activities associates with squares $22 \mathrm{D}-\mathrm{E}$ and a wider zone of squares 21-23 D-E (Fig. 3). Two to three centimetres thick, the lowermost part of the culture-bearing layer on this area represents a dense mass of dark coloured sediments containing numerous sooty and ashy particles and charcoals, fragments of burned bones, small knapped flints, retouched items, faunal remains, etc.

Many features witness the principal conservation of the original spatial structure of the layer. Thus, layer I yield few groups of bones found in anatomical order. Micro clusters containing flint debris of the same type of raw materials have been observed, indicating discrete episodes of stone working. More than twenty refittings highlight the links within clusters and migration of artefacts over the site area. A special case is discovered in square $19 \mathrm{~V}$ a very compact, probably previously wrapped in something, the cluster of flakes and micro-flakes. Evidence of discrete activities is witnessed also by concentrations of non-siliceous lithics. For instance, more than a half of the total number of amphibolite fragments was found within the area of square $23 \mathrm{Zh}$, while a larger portion of fragments of fossilized wood was found in square $21 \mathrm{D}$. There are areas of comparative concentration of bone tools. Bone ornaments are also gravitating toward the limited area in the SE part of the excavation.

Regardless of size, bone fragments are unevenly distributed; there are areas of concentration and almost entirely free areas. The distribution of either larger or tiny bone fragments, either burnt or not, are different. Spatial distribution of remains of different animals also clearly demonstrates non-random regularities; for instance, three distinct areas dominated by horses, and areas with a high concentration of fox and reindeer bones, were identified. There are clear patterns in the spatial distribution of different parts of animals of the same species. A good instance is the different spatial position of "meaty" (proximal limb) and "not-meaty" (distal limb) parts of a carcass of horse, bison and further not defined ungulate. More valuable for consumption parts generally gravitate to the SE of the excavated area, while less valuable parts - as well as bones in the anatomical order - concentrate to the NW segment.

It is believed that the material and patterns identified to allow for the assertion that excavations between 1997 and 2013 have partially uncovered the peripheral and central parts of a relatively long-term seasonal occupation (Stepanchuk 2005; 2013; Stepanchuk et al. 2004; Hoffecker et al. 2014).

Household pits, postholes, hearth lenses, and likely remains of burnt wooden objects were recovered in layer I. Several postholes were also recognised below layer I, at the level of layers II/1 and II/2. Postholes are close in style and location but rather different in details. In particular, their ends might be blunt or pointed, burned or not. Terminations might be pointed cone-like or pointed triangular in crosssection. Some of the stakes were fastened with casual material like bone splinters; sometimes stakes were placed in pairs. The diameter of postholes varies between 3 to $16 \mathrm{~cm}$ and small diameters prevail. As anthrocology analysis witnesses (Haesaerts et al. 2014), pine - either Pinus sy/vestris or Pinus mugo - is the only tree species identified among the charcoal samples from the upper layer. Dendrologists state (Nikitin 1984; V.F. Rudenko pers. comm. 2004), that the trunk of pine with a diameter of only $3 \mathrm{~cm}$ can be from 2.4 to 3 meters long, trunk with a diameter of $5 \mathrm{~cm}$ can range between 4 to 5 meters long, and so on. It means the small sizes of postholes revealed in Mira cannot prevent the assumption the corresponding pine trunks were used in construction. On the other hand, the prevalence of thin trunks in construction is a possible indirect indication of the absence of thicker trees in the vicinity.

The peculiarities of the layout of postholes, patterns of distribution of various kinds of cultural remains, specific features and location of pits, hearths and other objects suggest that the southeastern part of the excavated area reveals remains of a surface dwelling structure (Stepanchuk 2004; 2013). Postholes form a rounded pattern. Layer I yields four lenses which filling was mainly composed of sooty and ashy materials and includes only a few isolated charcoals. The content of filling may indicate that the lighter material than wood, for instance, pine needles and dry grass, were used as a main fuel.

Zones of concentration of lithic tools and wastes are located as arc embracing the part of the structure that faces the present-day river (Fig. 3: 1). The back part of the mentioned rounded area created by the exterior postholes is practically devoid of lithic finds that makes a sharp contrast to the area facing the river. Most of the ornaments and fragments of 
engraved bone pieces found in layer I are associated with the area of the dwelling structure that faces the river (Fig. 3; 4). The only found at Mira human tooth was also recovered within the dwelling boundaries (Fig. 3:1, red diagonal cross).

Several pits were detected inside the contour of the dwelling (pits Nos. 5, 10, 14, 15, 16 and 18). The majority of them represents common household pits filled with regular remains typical for layer I, that is dark-coloured clayey sediments containing tiny pieces of charcoals, soot and ashes, small lithic and bone debris. Pit No. 10 is sharply peculiar, as its filling represents a spotty grey-greenish clayey sediment. This sediment is a direct analogy of a natural lithological matrix that includes remains of human activity at the level of layer I. As soon as this pit is located in the area where layer I is extremely rich in various remains and residues, one can suggest it was constructed before the area became a zone of intensive occupation activity. A fragment of a rib and fragments of a horse's tooth, as well as a compact group of charcoal and a flake of zeolitized tuff (Petrougne 2001-2003), were found on the bottom of the pit in its central part.

Further objects were recovered next to the construction, in the area that faced the river. Among these are sooty lenses constituting the likely evidence of temporary open smoky hearths, and a rather specific pit No. 28 that is likely an indication of a pole that has been intentionally installed and then demounted. The shape of this pit allows reconstructing the likely presence of a post with a diameter of ca. $15 \mathrm{~cm}$ and a depth no less than $30 \mathrm{~cm}$. The post has not decayed gradually but was removed and an abrupt depression has been formed, into which the sediments contained various debris begun to slide down and a sharp inclination of a culture-bearing layer in a periphery of the pit was formed.

In the area that faced the river few large charcoals and small concentrations of sooty masses were also recovered. The location of these remains could serve as a possible indication of the direction in which either an outer fireplace or accumulation of fire wastes was located.

A dense dark-coloured layer of one to three $\mathrm{cm}$ thick and irregular outlines, containing a significant number of tiny fragments of burnt bone and flint was traced generally within the outer, rounded contour of dwelling and is especially rich in the part facing the river. This specific layer did not cover all the dwelling area continuously, displaying a narrow break strip in a central zone that marks the presence of some kind of barrier. We interpret this barrier, most likely presented by a piece of trunk, as a special partition dividing the outer and inner part of a dwelling. The marked difference in the saturation of sediments inside the outer circular outline by various residue makes it possible to distinguish between the likely sleeping and working areas of the dwelling. The entrance to the dwelling most likely turned towards the river (Stepanchuk 2004; 2013).

\section{DWELLING OF MIRA LAYER I: SOME ASPECTS OF THE CONSTRUCTION PROCESS}

Arguments for assessment of season and duration of occupation, habitat characteristics, and specific features of economic activities are presented elsewhere (Stepanchuk et al., 2004; Matviishina 2013; Gerasymenko, Haesaerts 2013; Stepanchuk 2013; Hoffecker et al. 2014; Haesaerts et al. 2014; Zhuravlev 2015). As It is suggested, a human group had entered the site area close to the autumn. A camp for wintering has been arranged on a low cape or floodplain elevation soon after successful hunting a harem horse herd. The occupation lasted through the winter and camp was abandoned in spring.

The process of constructing a surface dwelling seems to have started with an arrangement of peculiar pit No. 10 performed on an area previously minimally used for any activity. It is also possible that the construction of this pit marked the beginning of the occupation of the site as a whole. The pit, with a diameter of about $25 \mathrm{~cm}$ and a depth of about $16 \mathrm{~cm}$, contained a horse's rib fragment and tooth, few pieces of charcoal, and a flake of zeolitized tuff of not local origin. The finds found on the bottom of the pit, which seems to have been closed very soon after construction, principally resembles an offering of food, fire and stone tool and likely being a kind of special "construction offering", survived in some traditional cultures (Sodnompilova 2005). However, the location of the pit later appeared to be inside the dwelling was marked by a large fragment of a giant deer antler.

The next step of construction likely constituted a marking by steps the basic construction layout (for argumentation see Stepanchuk 2004). After that the structure's frame itself was erected, that is various burnt and pointed stakes were installed according to the previous markings and as a result, the central quasi-rectangular and external sub-round structural units were built.

If the central structural unit consisted of seven poles, the inner and outer units correlate asymmetrically. This in turn suggests that they could be constructed ad hoc, possibly not in parallel; the outer contour complements the inner one. In a case, the central constructive unit consisted of five poles this asymmetry is excluded, and therefore it is more likely the entire structure was erected synchronously. Finally, it may well be that large and deep pits do not necessarily correlate exclusively with the high posts. It is possible that some of these massive posts served to provide the internal arrangements of the 
dwelling, so they may have been short. This is particularly relevant in the case of pits (and hence the posts) which were situated close to the outer rounded outline of the structure. In this case, only three or four massive posts, possibly inclined slightly towards each other and presumably connected at the top by crossbars, might present a central constructive element of the structure and have provided its safety (Fig. 3: 3, 4).

It might be supposed that after finishing construction the frame was covered with a local material like skins, reeds, branches, etc. It should be stressed, however, that covering the entire surface of construction, requires 20 to 30 horse skins (Konstantinov 2001, with references), while only 10 to 15 skins were obtained during a successful horse hunt in the vicinity of the site. Probably at the moment when it became understood how the dwelling would be located, in front of it, on the right side of the entrance, a pole which is evidenced by pit No. 28, was installed. This pole was intentionally uninstalled after wintering when the site was abandoned.

A regular well visible permanent hearth was not detected in the dwelling. A possible reason is the presumed scarcity of wood in the vicinity and the use of bones as an essential component of available fuel also including light branches, grass and reed. It was argued that bone fuel is less efficient than wood fuel (Théry-Parisot et al. 2005), but in the face of wood scarcity bone use was undoubtedly reasonable. It cannot be excluded that heating the dwelling was provided by burned bones and charcoals systematically procured from an external fire and probably supplemented by the light inner fire(s), whose boundaries were not traced. On the contrary, the boundaries of the smoky fires of the warmer autumn time seem to be well traced on the outer contour of the dwelling (Fig. 3). Such hearths in due time provided the needed protection from the numerous blood-sucking insects that are very numerous in the river floodplain.

Most likely, the site and dwelling were abandoned by their inhabitants at the end of winter. In any case, there is no evidence of new productive hunting; nor is there any indication of the rebuilding or repairing of dwelling or the appearance of new objects on the inhabited area (like pits that partly destroyed earlier pits). The only traceable activity concerns the mentioned stand-alone pole that was dismounted from pit No. 28. The remaining stakes and poles were left in place, as evidenced by the pattern of spreading of the culture-bearing sediments in the immediate area around the postholes. For some time, the remains of the collapsing dwelling served as a refuge for small rodents, as witnessed by relatively numerous bone remains just in this area of excavation. Subsequently, the remains of the occupation and dwelling were gradually covered by alluvial deposits and then submerged for a long time.

\section{DISCUSSION AND CONCLUSION}

Remains of dwellings have been recognised in course of excavations and post-excavation interpretations of many Upper Palaeolithic sites in Eastern Europe (Abramova 1997; Anikovich et al. 2008; Belyaeva 2002; Chubur 2011; Gavrilov 2016; Pidoplichko 1969; Rogachev 1970; Rogachev, Anikovich 1984; Sapozhnikov, Sapozhnikova 2002; Sergin 1974; 1992). They show a raw of variants, both in layout, constructive materials and elements (e.g. Boriskovsky 1958; Rogachev 1970; Sergin 1988; Chubur 2016). However, there are no direct analogies to the construction of the site of Mira among these materials. One possible reason for this is the older age of Mira layer I and therefore less complex construction of Mira dwelling. A further reason for the lack of close analogies is probably the special conservation of the site of Mira. Details that enabled the recognition of the Mira surface dwelling are usually do not survive in the context of open-air sites which for a long time remain exposed for weathering and various post-depositional transformations. The rapid albeit gentle overlapping of the settlement remains with alluvial sediments ensured that the original settlement and dwelling patterns and their elements survived well. Most of the East European Upper Palaeolithic dwellings in the region belong to the so-called bone and earth dwellings of different types (Anikovich et al. 2008; Gladkikh et al. 1984; Popov 2002; lakovleva, Djindjian 2014; 2018; Pidoplichko 1969; 1976). The site of Mira lacks large bones or stones relevant to the construction. Layer I was inhabited by horse-hunters in an area where there was no stone, but there were pine trees and reeds which were likely used for the construction of the dwelling.

Archaeological evidence witness that poles were used as the main constructive element of Mira layer I roughly circular surface dwelling. Searching for ethnographic analogies among light carcass dwellings, in particular among dwellings of traditional Siberian peoples (Popov 1961; Arutyunov et al. 1991) show no direct analogies here either. Perhaps, effects of the inadequate level of details of the archaeological source, and also too large a chronological, respectively, the technological gap between the archaeological and ethnographic data. Nevertheless, it is possible to refer the Mira layer I dwelling to a permanent skeleton cylindrical structure of yaranga type, according to the classification of A.A. Popov (1961).

Should be emphasized the absence of a welltraced isolated fireplace in the dwelling of Mira 
that makes a clear dissonance with numerous archaeological and ethnographic evidence (Abramova 1997; Konstantinov 2001; Popov 1961; Sapozhnikov, Sapozhnikov, 2002). The probable lack of permanent fire may indicate that we may deal with a light dwelling, not intended for wintering, and the true winter dwelling is located somewhere nearby, but not revealed by excavations. However, it is more likely that the main hearth location was not identified because of the ash and soot mass, which hide it. Similar though chronologically more recent evidence is reported by archaeological and ethnographic sources (Taksami 1961; Zdanovich 1983). In this case, the hearth was, therefore, neither significantly deepened nor lined. Another possible explanation must allow for an insufficient supply of more common wood fuel; in that case, bones may have been the main fuel used. In which case it might have been more rational to use already burnt bone mass as a heater, rather than to fire fresh bone inside a dwelling.

Within the presented, irregular round in plan, with an area of about 14.5 square meters and diameter of somewhat more than $4 \mathrm{~m}$., Mira layer I surface dwelling were identified 38 post holes, four smoky hearths, and several household pits. The entrance was oriented towards the river, as in many archaeological and ethnographic instances (Kulemzin, Lukina 2006; García-Diez, Vaquero 2015). A supposed not utilitarian pit containing the likely «construction offering" was revealed within the dwelling. Next to the structure, to the left of the supposed entrance, there was a pole that was intentionally removed at the end of the occupation (Fig. 5; 6). The front part of the dwelling contained more than a third of all found knapped flints, more than a half of all tools, almost all tooth pendants and engraved bone items, as well as such peculiar findings as a human tooth, broken bone needle, and fragmented amber pendant. The back part of the dwelling, likely separated from the front part by a special partition, yields almost no residues. These data suggest that there is a clear division into slipping and intense working activity areas.

A 30,000-year-old Mira layer I surface construction currently represents the oldest dwelling known in the Upper Palaeolithic of Ukraine and a broader context of the steppe zone of the East European plain.

\section{REFERENCES}

Abramova, Z.A. 1997. Dwellings and settlements in the Paleolithic of the Russian Plain. Vol. 3, Sankt-Peterburg, pp. 5-80. (in Russian)

Anikovich, M.V., Anisyutkin, N.K., Vishnyatsky, L.B. 2007. Key problems of Middle-Upper Paleolithic transition in Eurasia. Proceedings of Kostenki-Borschevo archaeological expedition. Vol. 5. Sankt-Peterburg: Nestor-Istoriya. (in Russian)

Anikovich, M.V., Popov, V.V., Platonova, N.I. 2008. Paleolithic of Kostenki-Borschevo region in the context of Upper Paleolithic of Europe. Sankt-Peterburg: Nestor-Istoriya. (in Russian)

Anisyutkin, N.K. 2013. Mousterian site Ketrosy in the context of the Middle Paleolithic of Eastern Europe. Sankt-Peterburg: Nestor-Istoriya. (in Russian)

Arutiunov, S.A., Vasilyev, V.I., Dzharylgasinova, R.Sh. 1991. Ancient Uralic-East Asian parallels (the case of dwelling). Soviet etnography, 2, pp. 28-36. (in Russian)

Belyaeva, V.I. 2002. Palaeolithic site of Pushkari 1 (characteristics of the cultural layer). Sankt-Peterburg, St.Petersburg University. (in Russian)

Boriskovsky, P.I. 1958. Study of Paleolithic dwellings in the Soviet Union. Soviet Archeology, 1, pp. 3-19. (in Russian)

Chernysh, A.P., 1982. Multilayer Paleolithic site Molodova I, in: Goretskiy, G.I. and I.K. Ivanova (eds). Molodova I. Unique Mousterian settlement in the Middle Dniester. Moscow: Nauka. pp. 6-102. (in Russian)

Chernysh, A.P., 1987. The standard multilayered site Molodova V. Archeology, In: Ivanova, I.K., Tzeitlin S.M., (eds.), The multilayered Paleolithic site Molodova V. The Stone Age men and environment. Moscow: Nauka. pp. 7-93. (in Russian)

Chernysh, A.P. 1989. About the Mousterian dwellings and settlements. In: S.N. Bibikov (ed.) Kamennyj vek: pamyatniki, metodika, problem. Kiev: Naukova Dumka, pp. 72-81.

Chernyshov, S.S. 2006. Upper Palaeolithic dwellings. Archaeological monuments of Eastern Europe, 12, pp. 7-12. (in Russian)

Chubur, A.A. 2011. Palaeolithic of the Upper Dnieper region. Saarbrücken: LAP Lambert. (in Russian)

Chubur, A.A. 2016. The Settlement Structure in the Upper Paleolithic as a Migration Marker. Gardarika, 6(1), pp. 11-25. (in Russian)

Demay, L., Péan, S. Patou-Mathis, M. 2012. Mammoths used as food and building resources by Neanderthals: Zooarchaeological study applied to layer 4, Molodova I (Ukraine). Quaternary International, 276-277, pp. $212-226$.

Gerasimenko, N.P. 2001-2003. Evolution of pedosedimentation according to the main section of the Mira site, in: Stepanchuk, V.N. et al. Mira. New Late Pleistocene site on the Middle Dnieper (report on field research in the year 2000). Scientific Archive IA NANU, FE 2000/133. Kiev, pp. 42-49. (In Russian)

Gerasimenko, N.P., Haesaerts, P. 2013. Description of the litho-pedostratigraphy of the main profile. The northern wall of the main excavation, 2000-2001 data. Addendum in: Stepanchuk, V.N. Mira: the early Upper Palaeolithic site on the Dnieper, Stratum plus 1, pp. 99-101. (in Russian) 
Gladkikh, M., Kornietz, N. 1979. New construction of mammoth bones in Mezhyrichi. Visnyk AN URSR, 9. pp. 50-54. (in Ukrainian)

Gladkikh M.I., Kornietz N.L., Soffer O. 1984. Mammoth-Bone Dwellings on the Russian Plain, Scientific American, 251 (5), pp. 164-175.

Haesaerts, P., Damblon, F., Gerasimenko, N.P., Stepanchuk, V.N., Cohen, V.Yu., Kovalyukh, N.N. 2014. Stratigraphy, paleoenvironment and chronostratigraphic background of the Mira succession (Zaporozhiye, Central Ukraine), midway between Carpathians and Don, Études et rechereches archéologiques de l'université de Liège, 144, pp. 33-58.

Hoffecker, J.F., Holliday, V.T., Stepanchuk, V.N., Brugère, A., Forman, S.L., Goldberg, P., Tubolzev, O., Pisarev, I. 2014. Geoarchaeological and bioarchaeological studies at Mira, an early Upper Paleolithic site in the Lower Dnepr Valley, Ukraine. Geoarchaeology, 29, pp. 61-77. doi:10.1002/gea.21460

lakovleva, L., Djindjian, F. 2014. Le site d'habitat à cabanes en os de mammouths de Gontsy (Ukraine). Vingtième anniversaire des fouilles à Gontsy (1993 - 2013). Kiev : Service d'action culturelle de l'Ambassade de France en Ukraine.

lakovleva, L., Djindjian, F. 2018. The mammoth bone dwellings of the Upper Palaeolithic settlement of Gintsy (Ukraine): a First Synthesis. Arheologia, 4, pp. 86-94. (in Ukrainian)

García-Diez, M., Vaquero, M. 2015. Looking at the Camp: Paleolithic Depiction of a Hunter-Gatherer Campsite. PLoS ONE 10(12): e0143002. doi:10.1371/journal.pone.0143002

Gavrilov, K. N., 2016. Upper Paleolithic of Desna Basin. Continuity and variability in the development of material culture. Moscow-Sankt-Peterburg: Nestor-Istoriya. (in Russian)

Kulemzin, V.M., Lukina, N.V. 2006. Vasyugan-Vakhov Khanty in the late $19^{\text {th }}$-early $20^{\text {th }}$ centuries: ethnographic essays. Tyumen, Mandr and Ka. (in Russian)

Kunitsa, N.A. 2007. Priroda Ukrainy v plejstotsene (Nature of Ukraine in Pleistocene). Chernovtsy, Ruta. (in Ukrainian)

Konstantinov, A.V. 2001. Ancient dwellings of Transbaikalia, Paleolithic, Mesolithic. Novosibirsk: Nauka. (in Russian)

Matviishina, Zh.M. 2013. Mira, paleopedological studies. In: Stepanchuk V.M., Matviishina, Zh.M., Ryzhov S.M., Karmazynenko, S.P. Davnia liudyna. Paleogeografia ta arkheologia (Early man. Paleogeography and archaeology). Kyiv: Naukova Dumka, pp. 124-133. (in Ukrainian)

Matviishyna, Zh.N., Gerasimenko, N.P., Perederii, V.I., Bragin, A.M., Ivchenko, A.S., Karmazynenko, S.P., Nagirnyi, V.M., Parkhomenko, O.G. 2010. Spatial and temporal correlation of paleo-geographical conditions of the Quaternary period on the territory of Ukraine. Kyiv: Naukova dumka. (in Ukrainian)

Melnychuk, I.V. 2004. Paleolandscapes of Ukraine in Anthropogene. Kyiv, Obrii. (in Ukrainian)

Nikitin, K.E. (ed.) 1984. Assortment tables for taxations forest on the roots. Kiev, Urozhai. (in Russian)

Petrougne, V. F., 2001-2003. Petrographic data, in: Stepanchuk, V.N. et al. Mira. New Late Pleistocene site on the Middle Dnieper (report on field research in the year 2000). Scientific Archive IA NANU, FE 2000/133. Kiev, pp. 211-212. (In Russian)

Pidoplichko, I.G. 1969. Late Paleolithic dwellings of mammoth bones in Ukraine. Kiev: Naukova Dumka. (in Russian)

Pidoplichko, I.G. 1976. Mezhirich dwellings of mammoth bones. Kiev: Naukova Dumka. (in Russian)

Popov, A.A. 1961. Dwelling. In: M. G. Levin, L. P. Potapov (eds.) Istoriko-etnograficheskii atlas Sibiri. Moskva-Leningrad: Izdatel'stvo AN SSSR, pp. 131-226. (in Russian)

Popov, V.V. 2002. Dwelling of the Anosov-Mezin type at the Kostenki 11 site. Archaeological monuments of Eastern Europe, 9, pp. 4-11 (in Russian)

Rogachev, A.N. 1970. Paleolithic dwellings and settlements in Eastern Europe. In: A.A. Formozov (ed.) Kamennyj vek na territorii SSSR. Moskva: Nauka, pp. 64-77. (in Russian)

Rogachev, A.N., Anikovich, M.V. 1984. Late Paleolithic of the Russian Plain and Crimea. In: P.I. Boriskovskii (ed.) Paleolit SSSR. Moskva: Nauka, pp. 162-271. (In Russian)

Rudenko, L.G., (ed.) 2007. National Atlas of Ukraine. Kyiv: DNVP «Kartografiya». (in Ukrainian)

Sapozhnikov, I.V., Sapozhnikova, G.V. 2002. Late Paleolithic household and housing complexes of the steppe Ukraine. Kamiana Doba Ukrainy, 1, pp. 82-95. (in Ukrainian)

Sergin, V.Ya. 1974. Palaeolithic dwellings of the European part of the USSR. Moskva. (in Russian)

Sergin, V.Ya. 1988. Classification of Paleolithic settlements with dwellings on the territory of the USSR. Soviet Archaeology, 3. pp. 5-20. (in Russian)

Sergin, V.Ya. 1992. Palaeolithic settlements of the European part of the USSR, sites with a residential arrangement. Moskva. (in Russian)

Shydlovskyi, P.S., Tsvirkun, O.I., Péan, S., Chymyrys, M.V., Mamchur B.V. 2019. New study of fourth dwelling from Mezhyrich Upper Palaeolithic campsite: The results of international Summer School Activity. Vita Antiqua, 11, pp. 92-115. doi:10.37098/VA-2019-11-92-115

Sinitsyn, A.A., 2015. Perspectives on the Palaeolithic of Eurasia: Kostenki and related sites. In: Sanz, N. (Ed.). Human Origin Sites and the World Heritage Convention in Eurasia (HEADS 4) 1, 163-89. UNESCO, Paris, Mexico City.

Sirenko, S.A., Mel'nichuk, I.V., Turlo, S.I. 1990. Development of researches and reconstruction of Anthropogenic Paleolandscapes in Ukraine. In: A.M Marinich and M.M. Palamarchuk (eds.) Razvitie geograficheskoj nauki v Ukrainskoi SSR, Kiev, Naukova Dumka, pp. 50-63. (in Russian)

Sodnompilova, M.M. 2005. The semantics of dwelling in traditional Buryat culture. Irkutsk: Irkutsk Interregional Institute of Social Sciences. (in Russian)

Stepanchuk, V.M. 2004. Dwelling structure at the site of Mira. Arheologiya, 2, pp. 79-89. (in Ukrainian)

Stepanchuk, V.N. 2005. The archaic to true Upper Paleolithic interface: the case of Mira in the Middle Dnieper area. Eurasian Prehistory, 3(1), pp. 23-41. https://www.researchgate.net/publication/235996450 
Stepanchuk, V.N. 2013. Mira: the early Upper Palaeolithic site on Dnieper, Stratum plus, 1, 15-110. (in Russian) https://journals.indexcopernicus.com/search/article?articleld=1450964

Stepanchuk, V.N. 2019. Bifacial products of the upper layer of the site of Mira in the Dnieper region: the context, technomorphological features, and current interpretations. Prehistoric Archaeology: Journal of Interdisciplinary Studies, 2, pp. 5-34. (in Russian) doi:10.31600/2658-3925-2019-2-5-34

Stepanchuk, V. 2020. Studying the Lower and Middle Palaeolithic of Ukraine: main trends, discussions and results, in: M. Lilly, I. Potekhina, C. E. Budd (eds.), Prehistoric Ukraine. From the first hunters to the first farmers, Oxford \& Philadelphia, pp. 7-61.

Stepanchuk, V.M., Cohen, V.Yu., Gerasimenko, N.P., Damblon, F., Haezaerts, P., Zhuravlyov, O.P., Kovalyuh, M.M., Petrougne, V.F., Plicht, J., Puchkov, P.V., Rekovets, L.I., Turner II, C.G. 2004. The multilayered open-air site of Mira in the Middle Dnieper area: the main results of the 2000 field campaign. Kamiana Doba Ukrainy, 5, pp. 62-98. (in Ukrainian)

Stepanchuk, V., Petrougne, V., 2008. Stone raw materials of the site of Mira on the Middle Dnieper: variability and possible origin. Arkheologicheskiy almanakh 19, 75 - 86. (in Russian)

Stepanchuk, V.N., Vietrov, D.O. 2021. Paglicci 24A1 and Mira II/2: Episode at the transition between the Early and Middle UP. Quaternary International 587, pp. 277-290. doi:10.1016/j.quaint.2021.02.020

Taksami, Ch.M. 1961. Settlements, dwellings and household constructions of the Nivkhs on the Amur River and the western coast of Sakhalin Island (mid $19^{\text {th }}-$ early $20^{\text {th }}$ centuries). Siberian ethnographic collection, III. MoskvaLeningrad: USSR Academy of Sciences, 1961. pp.98-166. (in Russian)

Théry-Parisot, I., Costamagno, S., Brugal, J.P., Guilbert, R., 2005. The use of bone as fuel during the Palaeolithic, experimental study of bone combustible properties. In: Mulville, J., Outram, A.K. (eds.), The Zooarchaeology of Fats, Oils, Milk and Dairying, Oxbow Books, Oxford, pp. 50-59. https://www.researchgate.net/publication/260283715

Zdanovich, S.Ya. 1983. Settlements and dwellings of Sargara culture, in: Pshenichnyuk, A.Kh, Ivanov, V.A. (eds.) Settlements and dwellings of ancient tribes of the Southern Urals. Ufa: BFAN USSR, pp. 59-76. (in Russian)

Zhuravlev, O.P. 2015. The Osteological Materials from the Paleolithic Localities of the Lower Dnieper region and Crimea. Kiev: Oleg Filiuk Press. (in Russian).

Zhuravlev, O.P., Puchkov P.V. 2001-2003. Bone remains from the Palaeolithic site of Mira, in: Stepanchuk, V.N. et al. Mira. New Late Pleistocene site on the Middle Dnieper (report on field research in the year 2000). Scientific Archive IA NANU, FE 2000/133. Kiev, pp. 198-201. (In Russian)

Степанчук Вадим Миколайович'

1 д.і.н., провідний науковий співробітник Інституту археології НАН України

адреса: просп. Героїв Сталінграда 12, Київ, 04210, Україна

ORCID: 0000-0002-5476-2284

e-mail: vadimstepanchuk@iananu.org.ua

\section{НАЙДАВНІШЕ СВІДОЦТВО СПОРУДЖЕННЯ ЖИТЕЛ В ВЕРХНЬОМУ ПАЛЕОЛІТІ СХІДНОЇ ЄВРОПИ: НАЗЕМНА КОНСТРУКЦІЯ 3 I ШАРУ СТОЯНКИ МІРА ВІКОМ 30000 РОКІВ ТОМУ}

Перші свідоцтва про будівництво штучних притулків або жител в Східній Європі, що відносяться до пізнього етапу середнього палеоліту, були виявлені на багатошарових стоянках в західній частині географічного ареалу. Натомість рештки жител верхньопалеолітичого часу $\epsilon$ повсюдно поширеними. Широко відомою яскравою особливістю східноєвропейського верхнього палеоліту $є$ житла, побудовані з кісток мамонта. Наразі датування більшості східноєвропейських верхньопалеолітичних жител не виходить за хронологічні межі 12-17 тисяч років тому.

На стоянці Міра були виявлені залишки значно більш давнього житла. Стоянка Міра знаходиться в середній частині долини р. Дніпро. Рештки поселення добре збереглися і залягають на глибині близько 13 м від сучасної поверхні. Стратиграфічна колонка відкладів, що перекриває рештки поселення, охоплює суттєвий відтинок верхнього плейстоцену та голоцену. В нижній частині відклади містять три шари з археологічними знахідками, затиснені між двома піщаними тілами дніпровського алювію. Найбагатший верхній, І, шар являє собою рештки сезонного осінньо-зимового поселення, розташованого поблизу місця успішного полювання на гаремний табун плейстоценових коней. У південно-східній частині розкопу в шарі I виявлено кілька ймовірно неутилітарних та господарських ям, зачну кількість ямок від стовпів і кілочків, а також вогнища, зольники, скупчення кісток та кремневих артефактів і т.ін. Мікростратиграфічні особливості ділянки і закономірності просторового поширення різних категорій решток дозволяють розпізнати тут залишки наземного житла. Житло мало в плані неправильну округлу форму, діаметром дещо більше 4 м, зі входом орієнтованим до річки, площею близько 14,5 м². За особливостями конструкції житло можна віднести до постійних каркасних циліндричних споруд типу яранги. Радіовуглецевий вік шару І визначено в діапазоні від 31000 до 28000 каліброваних радіовуглецевих років тому, оттже конструкція шару I стоянки Міра на сьогодні $€$ хронологічно найдавнішим верхньопалеолітичним житлом, дослідженим в степовій зоні Східної Європи.

Ключові слова: верхній палеоліт, наземне житло, Східна Європа. 


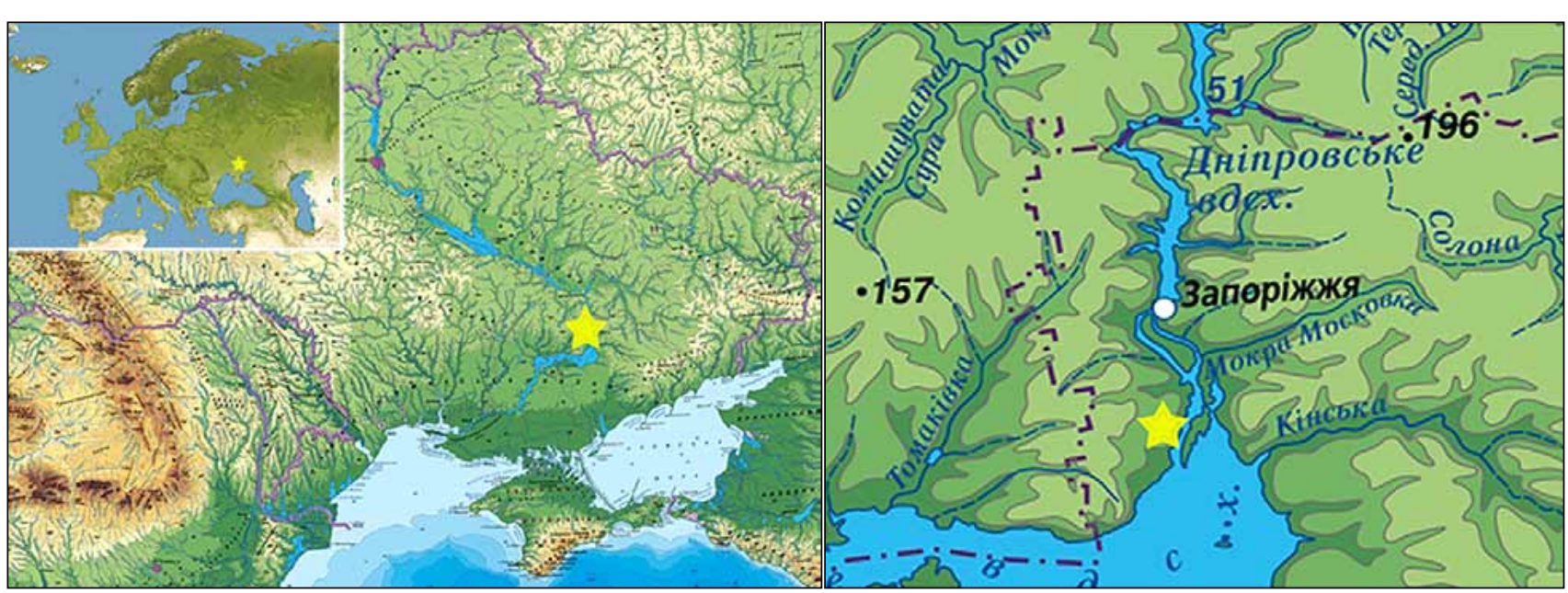

Fig. 1. Localization of the site of Mira.

Рис. 1. Розташування стоянки Міра.

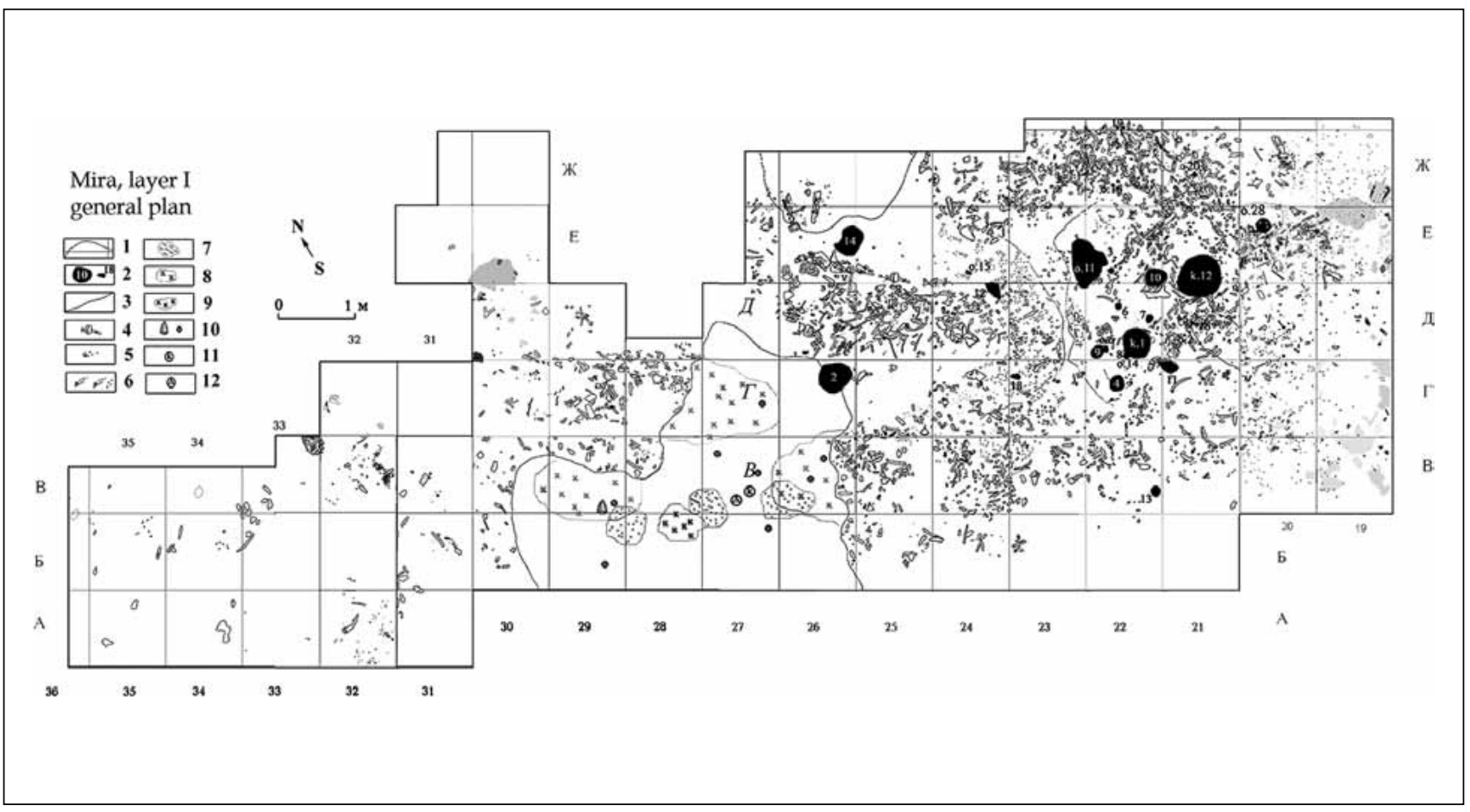

Fig. 2. Mira, excavations of 1997-2012. The general plan of finds of layer I. Key: 1 - border of amateur excavations of 1995-1996, 2 - objects (pits, postholes, hearths), 3 - border of an area rich in tiny charcoals and ash, 4 - bones, 5 - lithics, 6 - wood charcoals; graphic symbols for the area of amateur excavations 1995-1996: 7 - concentration of small flakes, 8 - big bones, 9 - burned bones, 10 - bifacial tool and large flake tools, 11 - stone, 12 - petrified wood.

Рис. 2. Міра, розкопки 1997-2012 рр. Загальний план знахідок шару І. Ключ: 1 - межа аматорських розкопок 1995-1996 років, 2 - об'єкти (ями, ямки, вогнища), 3 - межа ділянки, багатої на дрібні вуглики та золу, 4 - кістки, 5 - камяні вироби, 6 - деревне вугілля; графічні позначення для ділянки аматорських розкопок 1995-1996 років: 7 - скупчення дрібних лусочок, 8 - великі кістки, 9 - обпалені кістки, 10 - двобічні знаряддя і великі знаряддя на сколах, 11 - камінь, 12 - скам'яніле дерево. 


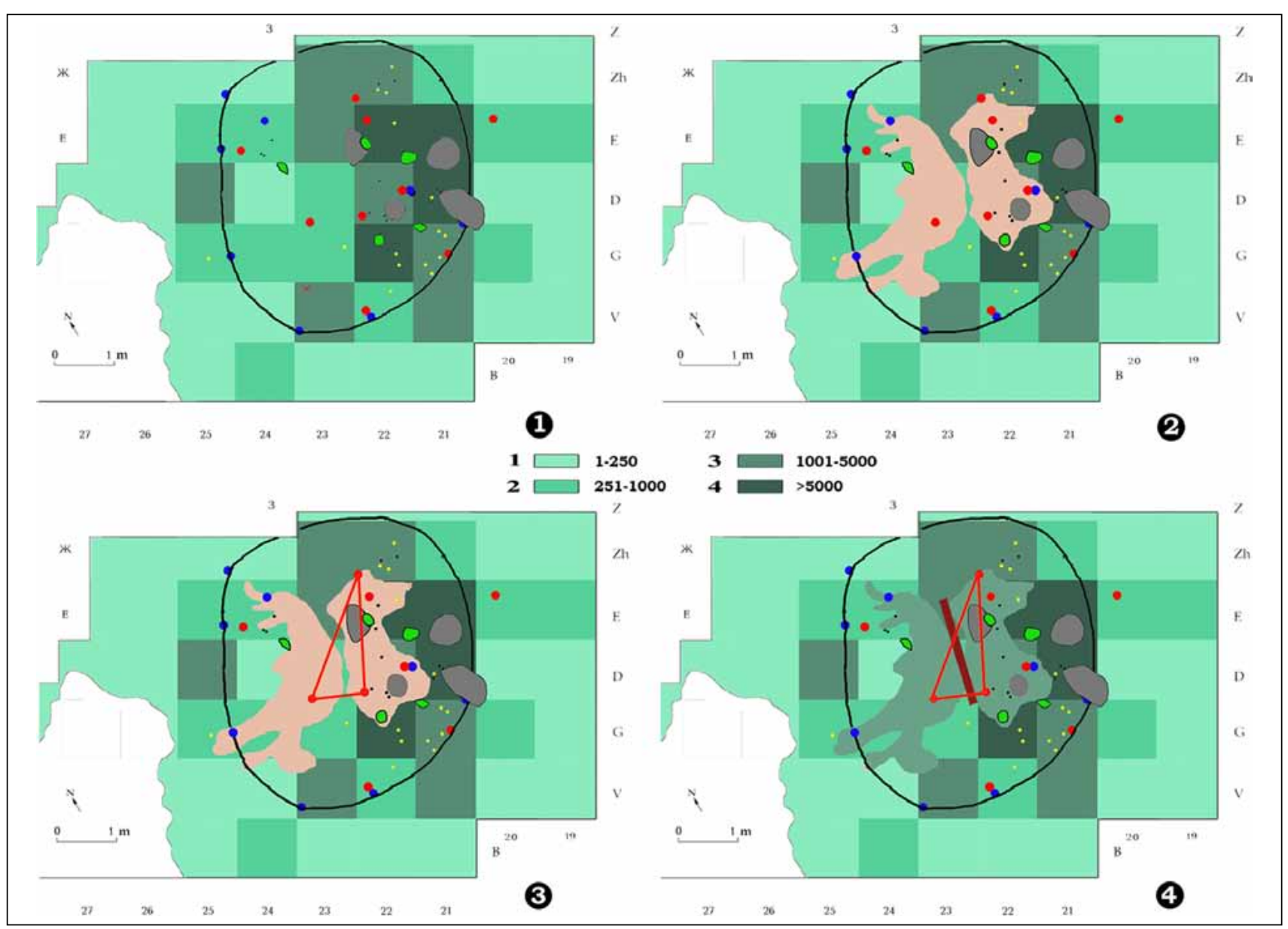

Fig. 3. Mira, construction of layer I. 1. The outer contour of construction against a background of flint artefacts frequency, with the position of hearths (grey), pits (light green), pierced carnivore teeth, art objects, bone tools (yellow spots), and human tooth (red diagonal cross). 2. Same, with the position of the dense mass, intensively stained with sooty and ashy particles and charcoals. 3. Same, with the presentation of the central three-pole constructive unit (red lines). 4. Same, with the position of a possible threshold (brown line).

Рис. 3. Міра, конструкція шару І. 1. Зовнішній контур споруди на тлі кількості крем'яних артефактів, з розташуванням вогнищ (сірим), ям (світло-зеленим), просвердлених зубів хижаків, предметів мистецтва, кістяних знарядь (жовті цятки) і зуба людини (червоний діагональний хрест). 2. Те $ж$, з позаченням розташування щільної маси, інтенсивно забарвленої сажистими і попеловимм частками і вугіллям. 3. Те ж, з позначенням центрального триполюсного конструктивного вузла (червоні лінії). 4. Те ж, з позначенням вірогідного порога (коричнева лінія).
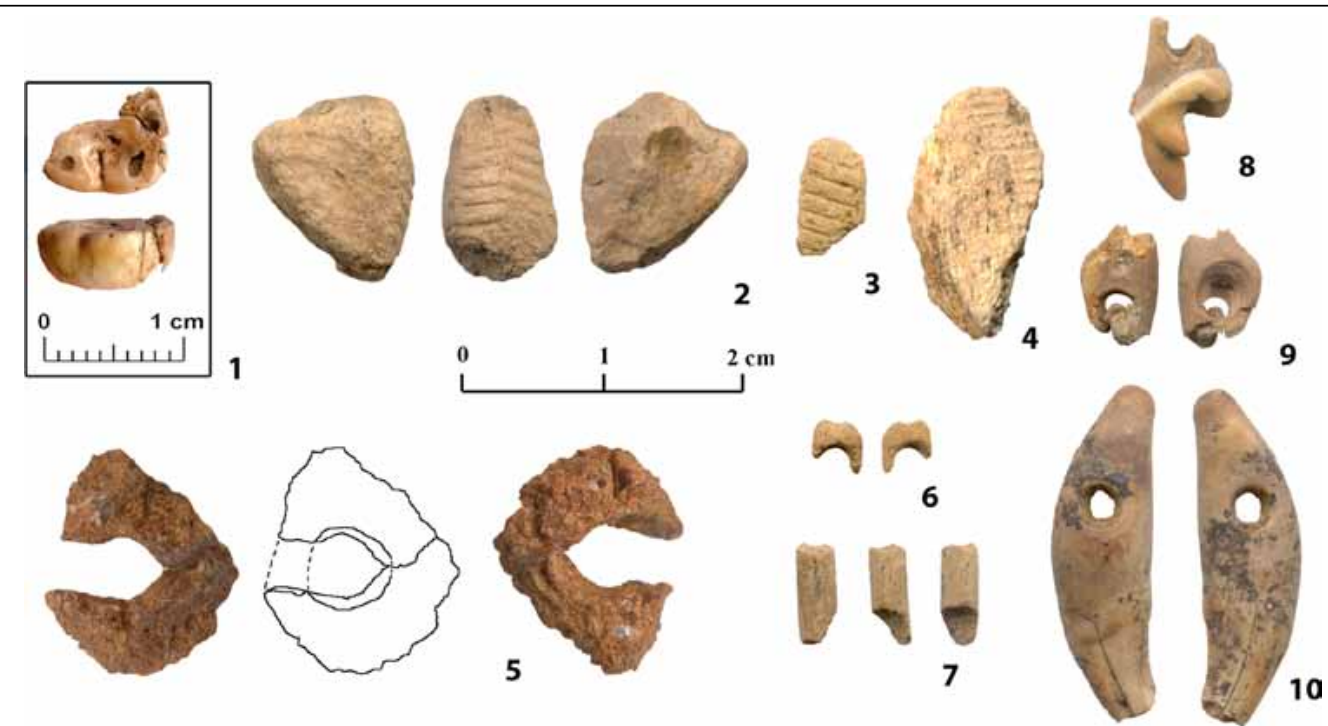

Fig. 4. Mira, finds from the dwelling construction of layer I. 1 - a fragment of a human tooth, 2-4 - articular and tubular bone fragments with engravings, 5 - amber pendant, 6 - a fragment of an eyed needle or a bead, 7 - needle fragment, 8-10 - pendants made of perforated teeth of small predators.

Рис. 4. Міра, знахідки з житлової конструкції шару І. 1 - фрагмент зуба людини, 2-4 - фрагменти суглобних і трубчастих кісток з гравіюванням, 5 - бурштинова підвіска, 6 - фрагмент вушка голки або намистини, 7 - фрагмент голки, 8-10 - підвіски 3 перфорованих зубів дрібних хижаків. 


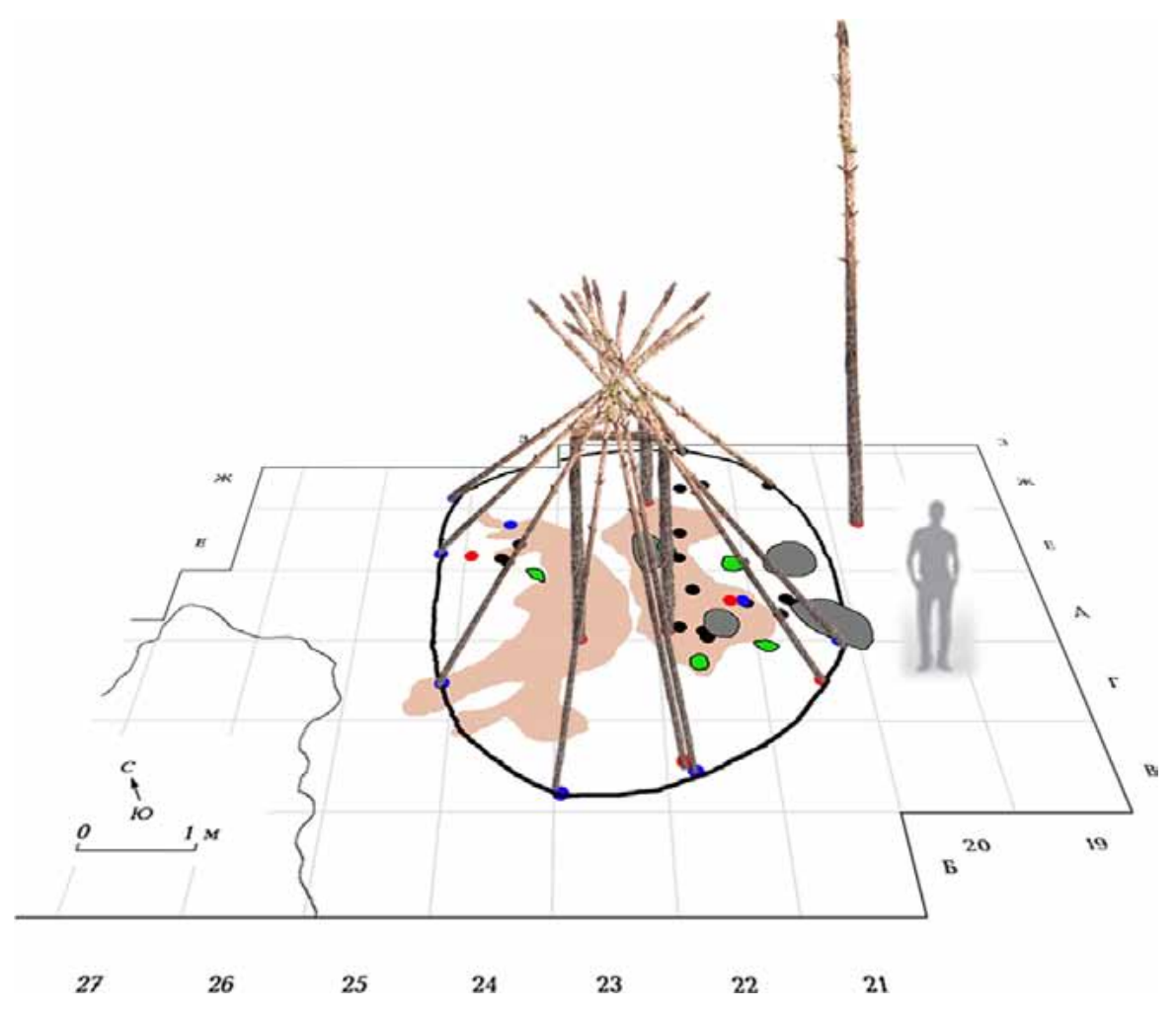

Fig. 5. Mira, construction of layer I. Tentative reconstruction with the central three-pole constructive unit.

Рис. 5. Міра, конструкція шару І. Ймовірна реконструкція з центральним триполюсним конструктивним вузлом.

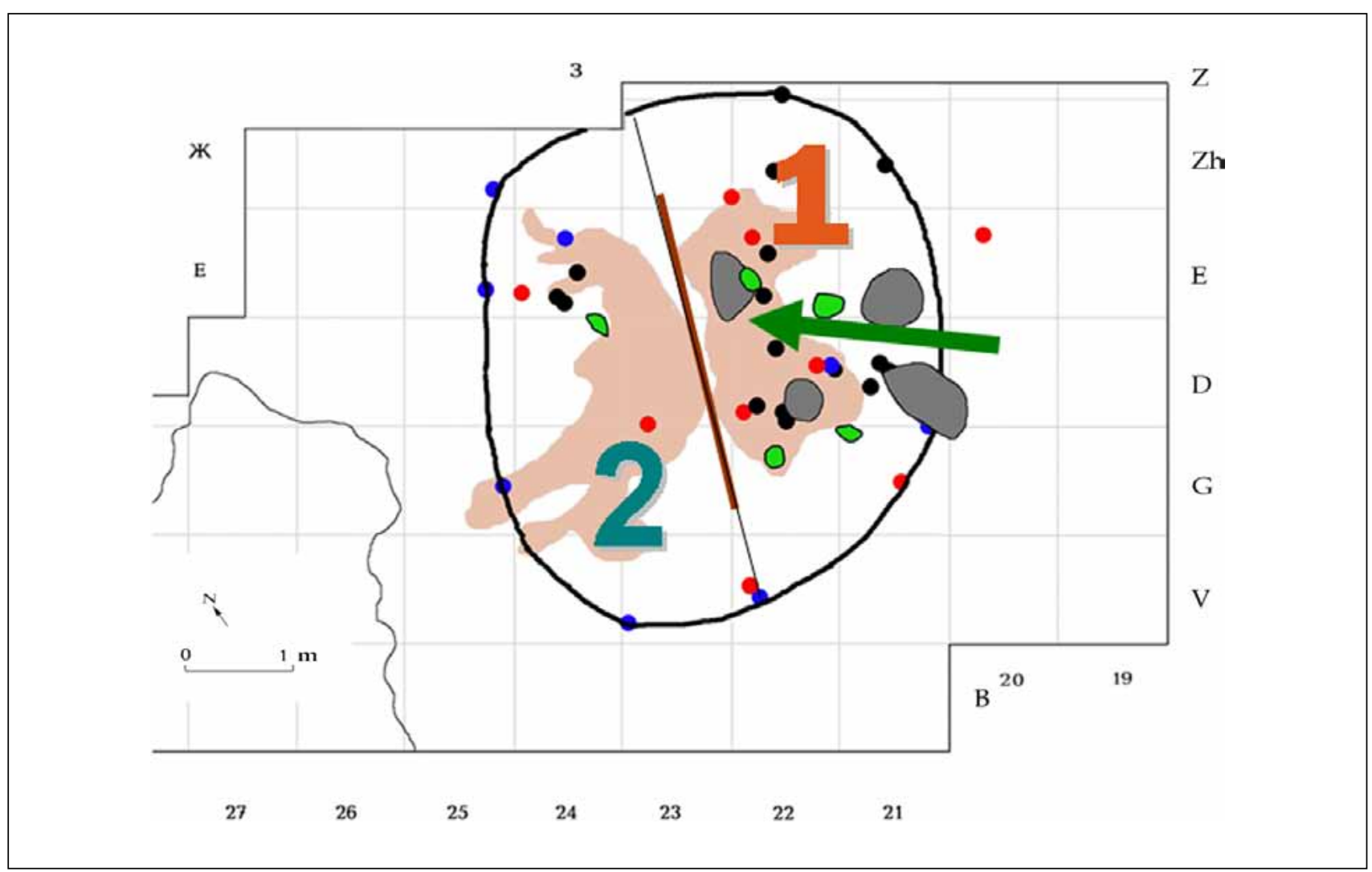

Fig. 6. Mira, construction of layer I. The main elements: entrance and intensive activity area (1), sleeping area (2), partition (brown line), entrance (green arrow), non-utilitarian pit No. 10 (violet, inside the contour), posthole pit No. 28 (red, out of the contour).

Рис. 6. Міра, конструкція шару І. Основні елементи: вхід і зона інтенсивної активності (1), спальна зона (2), перегородка (коричнева лінія), вхід (зелена стрілка), неутилітарна яма № 10 (фіолетова, всередині контуру), стовпова яма № 28 (червона, поза контуром). 
